\title{
62. kongres European Society for Cardiovascular and Endovascular Surgery 2013 v Řezně
}

Ve dnech 11.-13. dubna se $v$ krásném historickém městě Řezno konal již 62. kongres European Society for Cardiovascular and Endovascular Surgery (ESCVS). Díky České společnosti kardiovaskulární chirurgie (ČSKVCH) a udělenému cestovnímu grantu jsem měl možnost se tohoto významného setkání účastnit. Podmínkou udělení grantu byla aktivní účast. Přednesl jsem sdělení na téma „infekce a stentgraft" doplněné o zkušenosti z vlastního pracoviště a dále posterové kasuistické sdělení o řešení neobvyklé příčiny paradoxní embolizace a cévní mozkové příhody (pravé aneurysma vena poplitea). Celý program kongresu byl situován do prostorů Univerzitní nemocnice v Řezně, které poskytovaly dostatečnou kapacitu přednáškových místností i odpovídající technické zázemí, jež umožňovalo i přenosy z operačních a radiointervenčních sálů. Během odborných setkání zaznělo mnoho velmi hodnotných přednášek od řady autorů z celého světa. Osobně jsem se účastnil především sekcí věnovaných onemocnění aorty a karotid. Tématem, které spojovalo řadu přednášek, bylo endovaskulární řešení aneurysmat aorty a především komplikace této léčby. Při plánování léčby výdutí nebo disekce aorty bychom měli postupovat $u$ každého pacienta individuálně a zvažovat i možnosti fenestrovaných a větvených stentgraftů. Celosvětovým trendem je určitě odklon od používání CT angiografie při sledování pacientů po endovaskulární léčbě a nahrazení CT sonografickými metodami. Dle prezentujících autorů z mnoha pracovišt' má tato metoda velice dobré výsledky při detekci endoleaků. Do budoucna by mohla být péče o pacienty s implantovanými stentgrafty ještě zlepšena díky vývoji nových hybridních zobrazovacích metod a softwaru, s jejichž pomocí bychom mohli ještě zpřesnit diagnostiku endoleaků. Další diskutovanou komplikací endovaskulární léčby byla infekce. Diskutující se víceméně shodli, že metodou volby u léčby infekce stentgraftu by mělo být kauzální řešení - explantace stentgraftu a konzervativní léčba (samotná antibiotická léčba doplněná eventuálně o drenáž abscesu) by měla být volena jen zcela ojediněle. $\checkmark$ případě aorto-enterální píštěle je možné v léčbě použít stentgraft, ale jen jako „bridging” před definitivním operačním řešením. Ke zvážení je určitě návrh ponechávat při používání bifurkační cévní protézy delší tělo protézy, což by umožnilo použití stentgraftu $v$ prípadě nutnosti řešit anastomotické komplikace (pseudoaneurysma) nebo aneurysmatickou dilataci nad proximální anastomózou. $\mathrm{V}$ přednáškách věnovaných postižení karotických tepen byla často zmiňována důležitost morfologie aterosklerotického plátu a sonografického vyšetření. Bohatá diskuse byla také nad prováděním jednodobých výkonů na karotidách a srdci. Ve správně indikovaných případech má takovýto postup dobré výsledky. O přestávkách bylo možné navštívit řadu stánků vystavujících firem, které představovaly mnoho inovovaných nástrojů, cévních protéz, stentgraftů a př́strojů. I přes nabitý odborný program jsme měli možnost poznat i krásy historického centra města Řezno. Celkově na mne zanechal kongres výborný dojem a odnesl jsem si z něj řadu cenných poznatků. Tímto bych chtěl také ještě jednou poděkovat výboru ČSKVCH za možnost účastnit se kongresu.

MUDr. Karel Houdek, Chirurgická klinika, Lékařská fakulta Plzeň, Univerzita Karlova v Praze a Fakultní nemocnice Plzeň, e-mail: houdekk@fnplzen.cz 